Proc. Estonian Acad. Sci. Geol., 2005, 54, 2, 75-86

\title{
Harmonic and disharmonic soil-type interference on Late Pleistocene and Holocene sediments in Northeast Germany*
}

\begin{abstract}
Gerhard Reuter
Institute for Land Use/Soil Science, University of Rostock, D-18051 Rostock, Germany; gerhard.reuter@auf.uni-rostock.de

Received 28 February 2005

Abstract. Using colour photos and a specific horizon nomenclature, soil profiles in Northeast Germany are presented, which show characteristic features of harmonic development under recent climatic conditions, and disharmonic development with the joint appearance of Lessivé, BrownEarth, Podzol, and Pseudogley features on till. Taking into account studies in other climatic regions, the disharmonic development is interpreted as resulting from changing climate during the Holocene. Furthermore, in the relatively low-precipitation coastal area, a relict Chernozem (from the Boreal) has been subject to BrownEarth development. So-called Iron-Humus Podzols on older dune sands are reinterpreted as resulting from disharmonic development with ferralluviation during the Preboreal period.
\end{abstract}

Key words: soil types, soil development, change in climate, Holocene, Northeast Germany.

\section{INTRODUCTION}

The main principle for the recording and classification of soil diversity is the recognition of morphologically characteristic horizons. Initially, interest was concentrated on the extensive zonal soil types, whose diverse characteristics were formed by the prevailing climatic peculiarities and the resulting vegetation (e.g. the Brown Forest Soils of temperate-humid regions and the Chernozem or Black Earth Steppe Soil of semi-humid regions). Differences in geosubstrates and the resulting physical and hydrological peculiarities were recognized as the reason for the diversity of so-called intrazonal soil types (e.g. Gley and Alluvial Soils).

\footnotetext{
* The article is based on a contribution presented at the "Field Symposium on Human Impact and Geological Heritage" of the Peribaltic Group (INQUA Commission on Glaciation) and the "Friends of Baltic Quaternary" held in May 2003 in Tallinn, Estonia. Traditional German soil nomenclature is used here.
} 
The practice of soil survey very soon led - especially in temperate-humid regions - to the discovery of an immense diversity of soils that result from both the variations in the degree to which type characteristics are developed and the simultaneous occurrence of morphological features representing two or more different soil types within one and the same soil profile. We describe the latter phenomenon as soil-type interference (Reuter 1994) and distinguish the following categories, depending on their causes.

(1) Static soil-type interference can be caused simultaneously by different substratespecific or hydrological conditions at a site, e.g. short-range variation of soil parent material or ground-water influence beneath the top soil. Examples:

Pseudogley-BrownEarth and Gley-Podzol.

(2) Dynamic soil-type interference caused by the types changing during development. This can happen

a) under constant climatic conditions (= harmonic) or

b) through changes in the climatic conditions (= disharmonic).

The terms "harmonic" and "disharmonic" were derived from their application in geomorphology by Passarge (1912).

The examples that are presented here from Northeast Germany are from sites on Late Pleistocene marl with varying texture and on Holocene dune sand. The horizon terminology used corresponds to the Rostock genetic-morphological horizon nomenclature (Reuter 1958a).

Designations used in this paper:

O organic covering layer

$\mathrm{Oa}=$ Anmoor, $\mathrm{Om}=$ moder, $\mathrm{Or}=$ raw humus

A accumulation of humus in the mineral topsoil

As $=$ sour $(\mathrm{pH}<6.0)$, An $=$ neutral $(\mathrm{pH} 6.0-8.0)$

B brown weathering

$\mathrm{Be}=$ "earthy" (coagulated fabric), $\mathrm{Bl}=$ "loamy" (dispersed fabric)

E eluviation of colloids

$\mathrm{Eg}=$ by gleying, $\mathrm{El}$ = by lessivation, $\mathrm{Ep}=$ by podzolization

I illuviation of colloids

Ia $=$ argillic, Ih $=$ humic, If $=$ ferric

G ground-water influence

$\mathrm{Go}=$ oxidative, $\mathrm{Gr}=$ reductive

$\mathbf{P}$ pseudogleying

M mother substrate (unweathered), $\mathrm{Mw}=$ weakly weathered

Two prefixes are used here: $\mathbf{p}$ means ploughed, $\mathbf{r}$ indicates relict horizons.

\section{SOILS ON LATE PLEISTOCENE TILL}

Till sites in Northeast Germany are almost exclusively carbonate-containing sediments of the Late Pleistocene (Vistula $=$ Weichselian glaciation). The texture of these glacigenic substrates is very varied (clayey loam-marl to sandy marl), so 
that pedogenesis under the same climatic conditions leads to different soil types resulting from varying physically relevant conditions (percolation, aeration, root penetration).

\section{"Pure" soil types on till}

For a better understanding of what comes later, some of the "pure" (interference-free) soil types on Late Pleistocene till are described first.

We find Pseudogley when the till is rich in clay and silt and the compact fabric limits the processes of weathering, aeration, and percolation. Its typical characteristic is the clearly visible mottling which occurs not only in the Pseudogley horizon (P) but also in the underlying carbonate-rich till (MvP). Incidentally, the carbonate content is the reason for the eutrophic character of the Pseudogley in our region (Reuter 1960), quite in contrast to the Pseudogleys in carbonate-free substrates, for example in Saxony, which were identified earlier (Krauss 1928).

When the clay and silt content is lower $(<20 \%)$, the BrownEarth soil type develops under recent climatic conditions. The characteristic brown horizon, enriched with iron oxides, has a non-compact fabric with coagulated colloids, which guarantees balanced water and air regimes and therefore promotes root penetration.

At a few sites with the same texture as that of the BrownEarth, soils have been found with a typical Lessivé horizon sequence: under the A horizon lie the clayeluvial and the clay-illuvial horizons (El and Ia). Usually they are found on sloping sites where denudation can be expected. Our categorization of these relatively rare pedons as disharmonic relict palaeosols will be justified in the subsection "Disharmonic soil-type interference on till".

If pedogenesis occurs on till sites under the influence of ground water, Gley soils are formed with the characteristic horizons Go and Gr.

\section{Harmonic kinds of soil-type interference on till}

There is a wide variety of interference between the soil types occurring in Northeast Germany. In this paper only some examples of the well-known harmonic kinds of interference ( $=$ developed under recent climatic conditions) are mentioned. For terms consisting of two or more nouns, the name of the type which is morphologically most pronounced is placed in final position.

A loosening up by cultivation and the removal of surplus water by drainage can lead to the development of BrownEarth in the topsoil of a Pseudogley and thus to a marked increase in the fertility of the soil. The profile in Fig. 1 is a BrownEarth-Pseudogley. It is situated in the long-term experiment Hu2 near Rostock, in which international record yields were achieved (Reuter 1982). The reason for this is an ideal water regime: in years with very high rainfall the topsoil is sufficiently aerated by the drained Be horizon, and in dry years the P horizon performs a valuable water storage function. Where there is a higher proportion of 
sand in the topsoil, a Pseudogley-BrownEarth interference develops. If there is also a more sandy substrate below the $\mathrm{P}$ horizon influenced by ground water, an extended type interference may occur: BrownEarth-Pseudogley-Gley with the horizon sequence An-Be-P-Go-Gr (for picture see Reuter 2003b). If the sand content of the till is very high, development in the topsoil has gone beyond the stage of BrownEarth, by more or less intensive secondary podzolization. We find the harmonic type interference Podzol-BrownEarth (Fig. 2).

\section{Disharmonic soil-type interference on till}

The most frequent soil-type interference on the Late Pleistocene till in Northeast Germany comprises characteristics of lessivation, i.e. clay-eluvial and clay-illuvial horizons, combined with other soil types, in particular BrownEarth. They were discovered here some time ago (Reuter 1957, 1958b) and compared with similar soils on loess (Dudal 1953; Kubiena 1956). Regarding the pedogenic interpretation, two hypotheses were considered: (1) the secondary development of a Lessivé from a BrownEarth and (2) the secondary development of BrownEarth from an earlier Lessivé. Mückenhausen (1957) preferred the first variant for corresponding soils on loess and introduced the name "Parabraunerde". We support the second explanation, especially after intensive studies of relevant soils in different climate zones in Europe and North America (Reuter 1964a, 1968). In what follows, the various forms of Lessivé interference will first be presented. Afterwards, the pedogenic interpretation will be discussed and the relict character of the Lessivé features explained.

Figure 3 shows the type-interference of BrownEarth and Lessivé. One recognizes the relatively weakly developed BrownEarth horizon Be under the organic layer of moder Om and a sour A-horizon As. Below the pedogenically recent zone the characteristics of lessivation are more clearly visible. We regard these as relict in character (explanation follows later), therefore we use the terms rEl and rIa ("a" means argillic).

The type-interference between BrownEarth and Lessivé on sites with till is the general rule in our region. However, there are considerable differences in the degree to which such components are actually developed, depending on texture and other factors. In Fig. 4 we see an extreme case. Here, the secondary BrownEarth formation is so strongly advanced that the characteristics of lessivation are scarcely visible. Identification was made micromorphologically, showing only a few proportions of double-refracting mineral colloids in the subsoil.

Frequently, Late Pleistocene till was structured by cryoturbation under periglacial conditions. Within these structures, characteristic features of lessivation are clearly visible (see Fig. 5). In the topsoil moder changes into raw humus (Orm) and in the sour A-horizon As eluviation begins by podzolization: AsEp (not so clearly visible in the photo).

In very sandy geosubstrates of the ground moraine, no compact clay-illuvial horizon was created by lessivation, but a number of thin bands were formed 
(Fig. 6). In contrast to this, the BrownEarth horizon was formed later in the upper part of the profile to considerable dimensions.

If the intensive lessivation process has caused a strong texture differentiation, very varied secondary processes can occur in the profile (Fig. 7). In the more sandy topsoil we note only weak BrownEarth formation but we see very clearly the process of podzolization (with raw humus in the Or, and strong bleaching of the Ep). In the subsoil, mottling shows us that the horizon, which has been compacted by clay illuviation, is subject to the process of pseudogleying (rIaP). In this soil, then, interference results from the characteristics of four soil types.

This is also true of the profile in Fig. 8, which can be used to explain the relict character of the Lessivé horizons in our region: under the covering layer of raw-humus-like moder (Omr) the sour A-horizon is weakly podzolized - As(Ep), which is difficult to recognize in the illustration. Below this, the BrownEarthhorizon Be with its loose coagulated fabric, is well developed. A characteristic feature is the strong root penetration. The eluvial horizon $\mathrm{rEl}$, bleached by lessivation, is also easy to recognize. It merges into a strongly compacted argillic illuvial horizon, which here reaches $180 \mathrm{~cm}$ depth. The designation rIaP indicates that in this area, compacted by clay enrichment, a pseudogleying process has occurred and makes itself apparent as mottling. A micromorphological comparison of the horizons (Reuter 1964b) proved that the obvious polygenesis can certainly not be a transformation of BrownEarth into Lessivé as some other authors have assumed: in the argillic illuvial horizon the clay and silt particles are $90 \%$ strongly dispersed. This can be seen by the yellow colour which is the optical effect (double-refraction) caused by the parallel orientation of the so-called "flowplasma" (Kubiena 1956). In contrast to this, the BrownEarth horizon Be with its strongly coagulated fabric does not contain such oriented clay-colloids, which would be a prerequisite for dispersion and transport by the eluviation process.

To explain this pedogenically problematic discrepancy in the regionally very frequent interference between BrownEarth and Lessivé, we searched for regions in which these types have recently come into being without such interference. We found typical recent Lessivé development without any interference by BrownEarth in humid, relatively warm areas of southeastern Europe. Examples were investigated in Romania (Fig. 9) as well as in southern Bulgaria and Hungary (see photos in Reuter 2003a), all without any interference by BrownEarth, which is predominant in our region. An important argument for our view is the fact that in the relatively warm countries just mentioned an areal association of Lessivé and BrownLoam (terra fusca) was found. This type can be regarded as a preliminary stage for the lessivation process, since it contains strongly dispersed clay and silt (Kubiena 1956; Reuter 1964a, 1964b).

Sites with BrownEarth development without Lessivé or BrownLoam characteristics and without areal association with these types can be found in cooler areas, for instance in northern Europe and in higher mountain locations (Reuter et al. 1995).

These climatically relevant facts demand a substantial explanation. This is found in the well-known fact that the vertical transport of soil particles insoluble 
in water is made possible by hydrophilic substances (so-called "protective colloids"). In the process of podzolization these are organic substances (fulvicacids). They do not become effective in warmer humid regions, because of the lack of raw humus. Instead, there are high proportions of hydrophilic silicon compounds, which can become effective as "protective colloids" in the lessivation process.

The above mentioned findings concerning the different climatic relevance of Lessivé and BrownEarth suggest that the type interference, widespread in Mecklenburg-Vorpommern and neighbouring areas, can be explained by climatic changes during the Holocene. Humid-warm conditions prevailed during the Atlantic stage. They enabled the lessivation process to take place. Afterwards it became markedly cooler so that in the Subboreal and in particular in the Subatlantic stage the processes of BrownEarth formation and podzolization emerged and still prevail (Reuter 1990). The Lessivé characteristics in our region are palaeo-relics, for they cannot come into being under the recent climatic conditions. We did not find them in recent colluvial materials from unweathered sediments.

We found quite another disharmonic soil-type interference on Late Pleistocene till (Fig. 10). It occurs on the Island of Poel near the town of Wismar (Böttcher 1959). The annual precipitation in this coastal area is considerably lower than inland. It can be assumed that this effect also existed during the earlier stages of the Holocene. On sites where Late Pleistocene till has an especially high silt content, Chernozems with a deep A-horizon and relics of past animal burrowing (Russ. krotovina) appear. That this is a disharmonic formation is demonstrated by the clear degradation in the upper part of the topsoil. Here, simultaneously with lessening of the humus content, a weak recent BrownEarth development has started (horizon pAnBe). The Chernozem phase in this disharmonic type interference can only have taken place in the dry Boreal stage of the Holocene.

\section{DISHARMONIC SOIL-TYPE INTERFERENCE ON HOLOCENE DUNE SAND}

Investigating soil development on Holocene dune sand, we were struck by a phenomenon which also points to disharmonic type interference. On the Dar $\beta$ Peninsula, where the Holocene coastal dynamics and landscape development can be properly reconstructed and dated, there is a cliff of the former Litorina Sea. It separates the "New Darß", which was formed in the Postatlantic stage, from the "Old Darß", which already existed during the Atlantic stage.

Our field work in the New Darß led to the discovery of recent Podzols, in which no differentiation between humic and ferric illuvial horizons could be made (Fig. 11). This is true of all the podzols investigated in the New Darß. Evidently, the simultaneous eluviation of hydrophilic organic substances and sesquioxides leads to a joint illuviation in the Ihf horizon. This stands in contradiction to experience with so-called "Iron-humus Podzols" that are widespread in Central Europe and in which clearly separate illuvial horizons Ih and If 


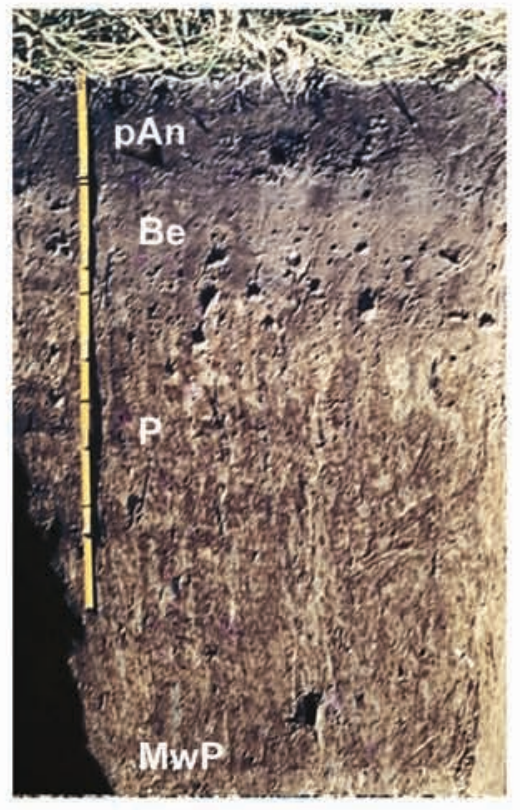

Fig. 1. BrownEarth-Pseudogley.

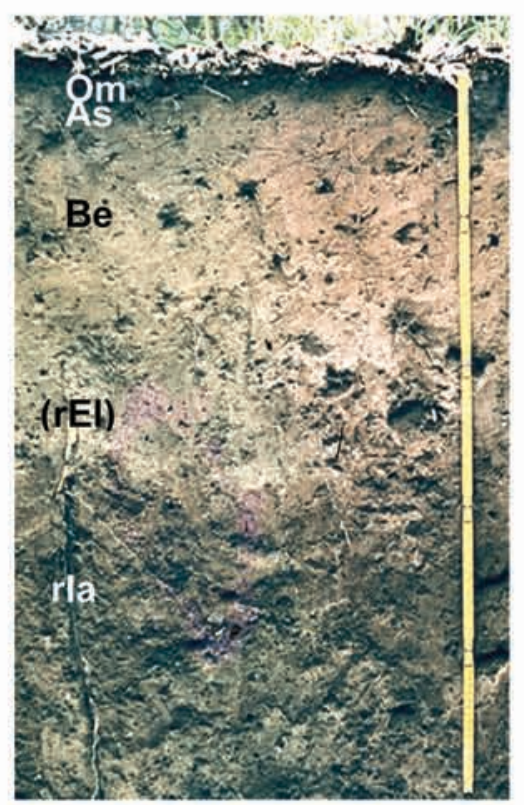

Fig. 3. BrownEarth-rel.Lessivé.

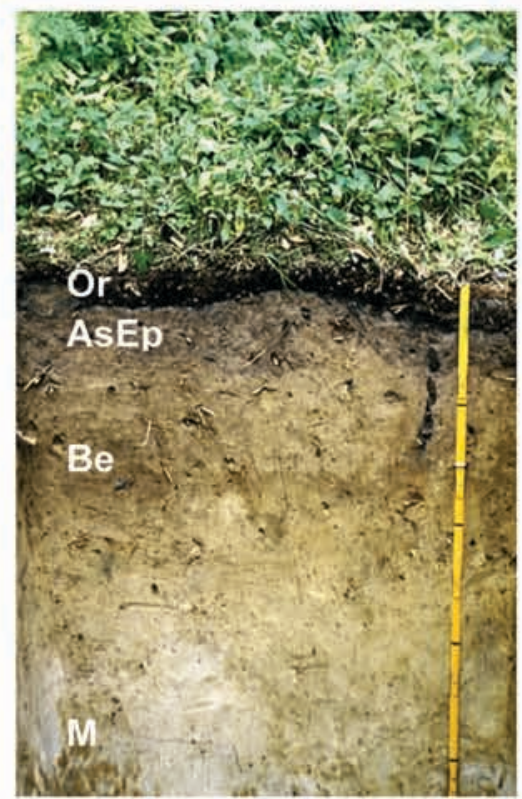

Fig. 2. Podzol-BrownEarth.

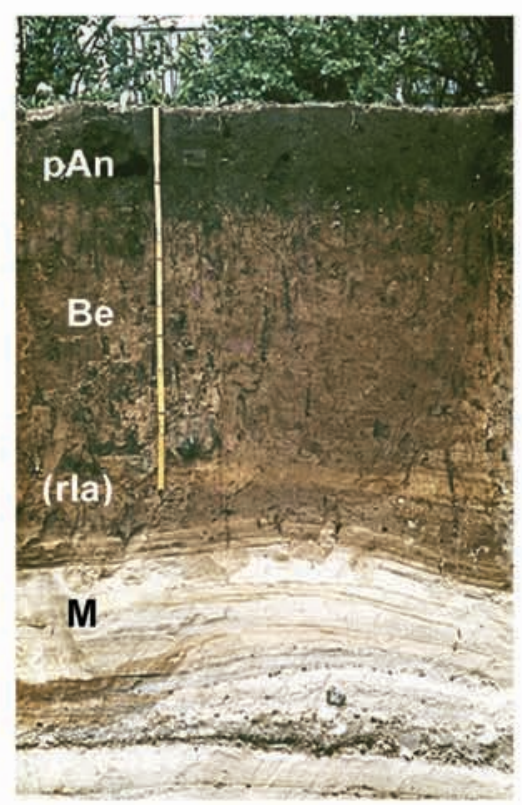

Fig. 4. (Rel.Lessivé)-BrownEarth. 


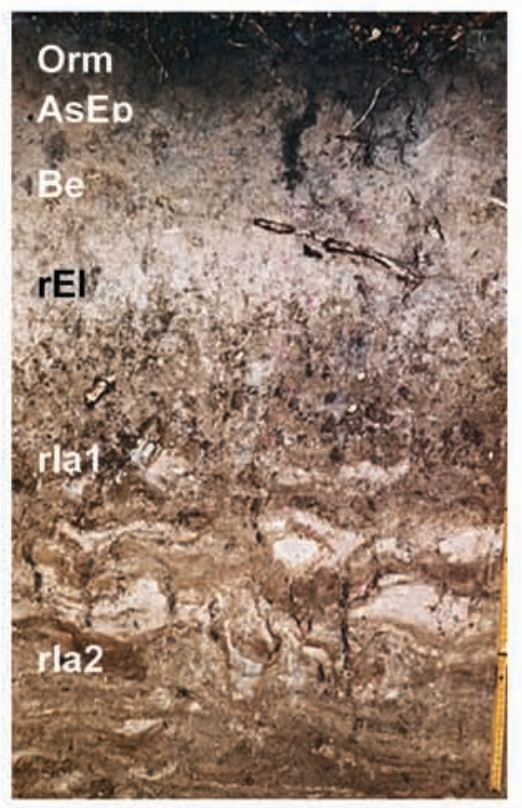

Fig. 5. (Podzol)-BrownEarth-rel.Lessivé.

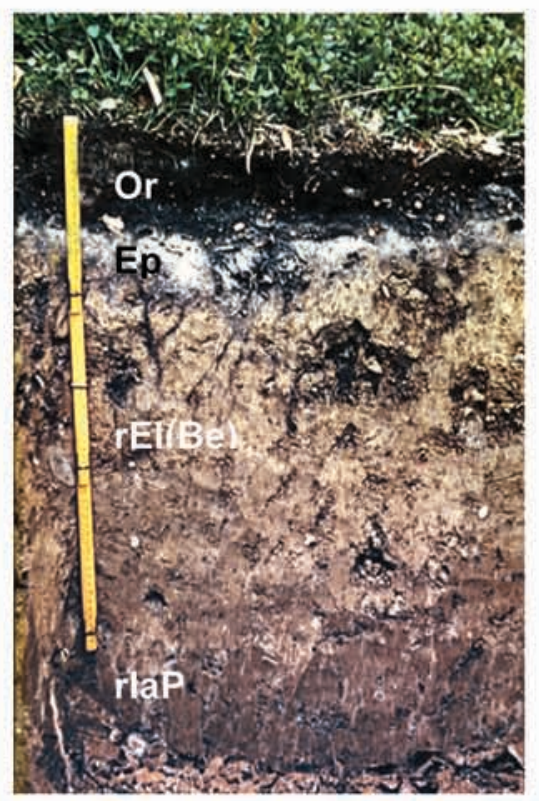

Fig. 7. Podzol-(BrownEarth)-Pseudogley-rel.Lessivé.

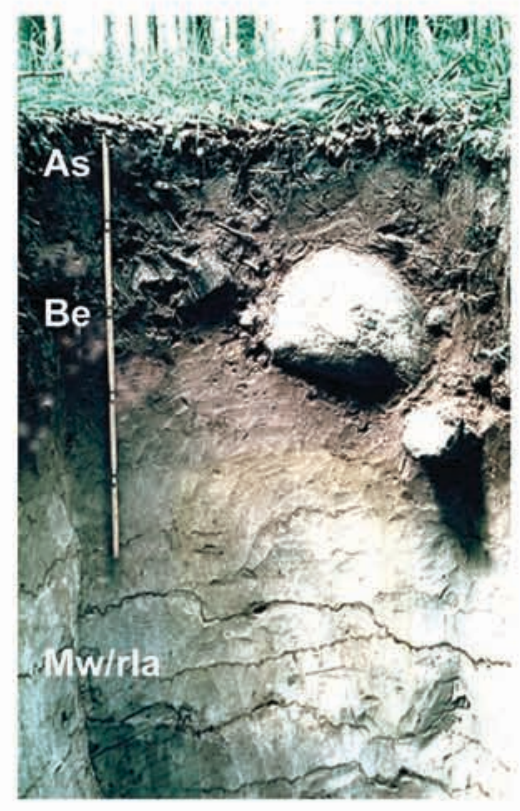

Fig. 6. (Rel.Lessivé)-BrownEarth.

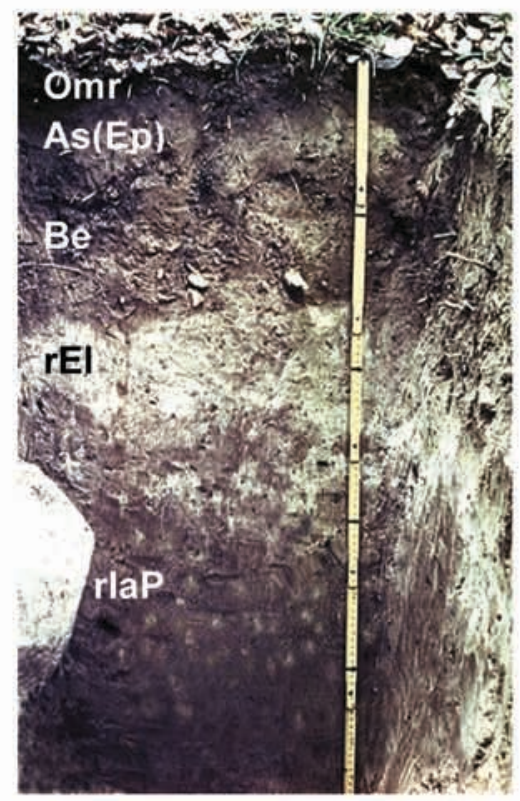

Fig. 8. (Podzol)-BrownEarth-Pseudogley-rel.Lessivé. 


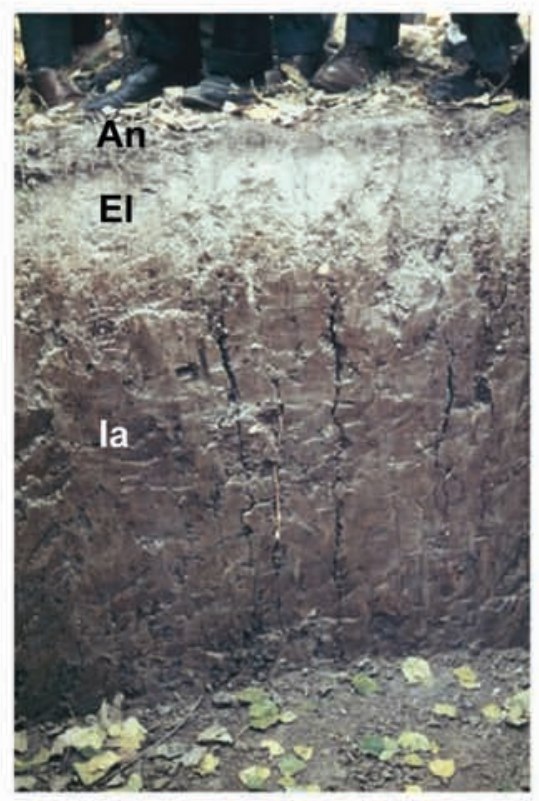

Fig. 9. Lessivé in Romania.

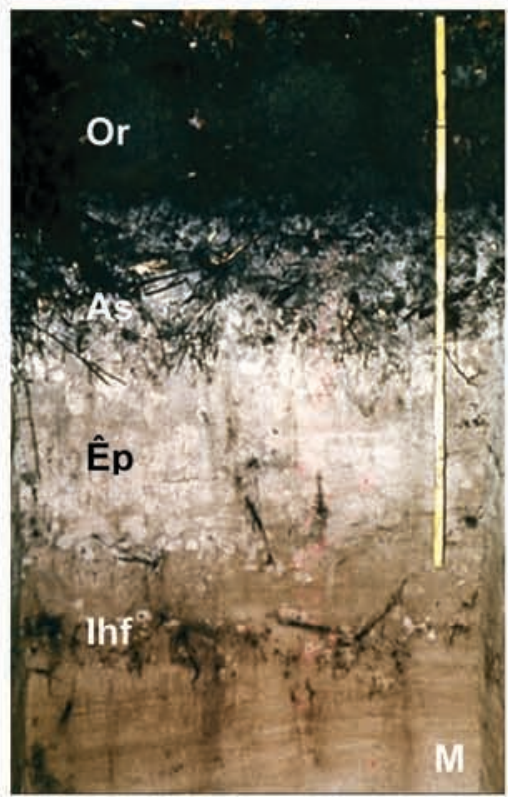

Fig. 11. Podzol.

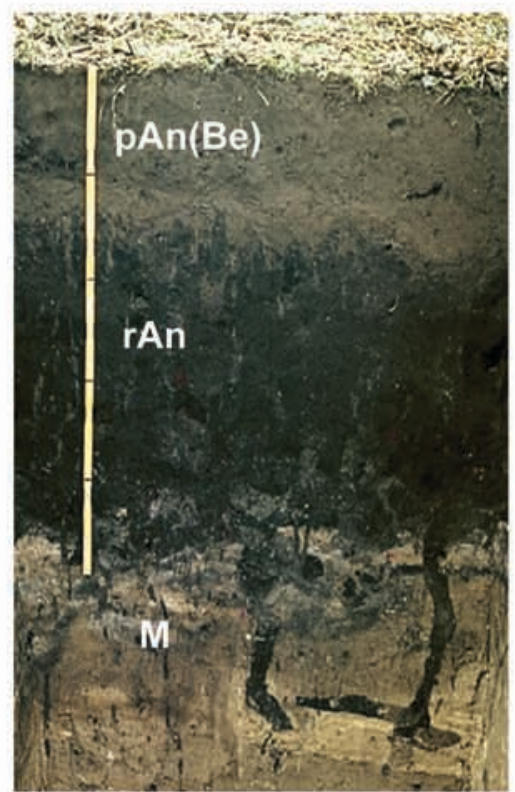

Fig. 10. (BrownEarth)-rel.Chernozem.

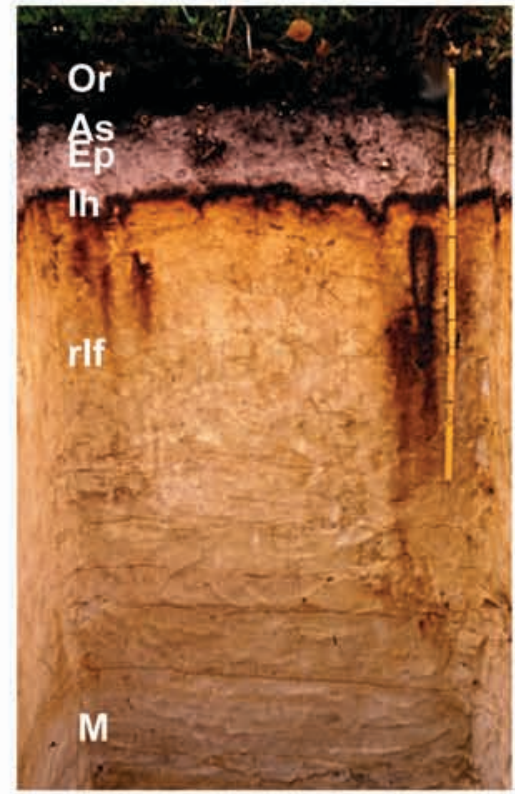

Fig. 12. Rel.Ferralsol-Podzol. 

appear. This is also the case with the Podzols in the Old Darß, where the Ih and If horizons can be clearly distinguished. As discussed in Reuter (1999), we interpret this phenomenon as disharmonic development-interference: the sesquioxides were eluviated by the process of ferralluviation during the relatively warm Atlantic stage to a fairly great depth, whilst the formation of raw humus and subsequent podzolization were not possible. But, these processes could take place during the cooler Subatlantic stage and almost exclusively organic substances were eluviated and deposited as an Ih-horizon on the surface of the relict If-horizon. This hypothesis is supported by the different depths of the two illuvial horizons and the demarcation between them, which is mostly very clear (Fig. 12).

\section{CONCLUSIONS}

In Central Europe the climatic alterations during the Holocene were of pedogenic relevance. We can demonstrate various palaeo-relict horizons from the Boreal and Atlantic stages, together with recent horizons from the Subatlantic stage, as various kinds of disharmonic soil-type interference, besides the wellknown harmonic ones. In order to bring out the influence of Holocene climatic change on soil development, it seems necessary to notice these findings and to mark the relict horizons by the symbol $r$. For the further clarification of disharmonic type interference, especially regarding identification of pedoprocesses under former climatic conditions, chemical and colloid-chemical analyses and model experiments should be more widely employed, in addition to the profile-morphological and micromorphological methods.

\section{ACKNOWLEDGEMENT}

Thanks are extended to J. Catt for improving the English text.

\section{REFERENCES}

Böttcher, H. 1959. Beschreibung und Untersuchung der schwarzerdeähnlichen Böden der Insel Poel. Diplomarbeit, Universität Rostock.

Dudal, R. 1953. Etude morpohologique et génétique d'une sequence de sols sur limon loessique. Extrait de l'Agriculture, 1, 121.

Krauss, G. 1928. Die sog. Bodenerkrankungen. Jahresbericht Deutsch. Forstvereins, 121.

Kubiena, W. L. 1956. Zur Mikromorphologie, Systematik und Entwicklung der rezenten und fossilen Lößböden. Eiszeitalter u. Gegenwart, 7, 101-112.

Mückenhausen, E. 1957. Die wichtigsten Böden der Bundesrepublik Deutschland, dargestellt in 60 farbigen Bodenprofilen mit Erläuterungen. Wiss. Schriftenreihe des AID, H. XIV.

Passarge, S. 1912. Physiologische Morphologie. Hamburg.

Reuter, G. 1957. Exkursionsführer in die Umgebung von Rostock. Tagung der V. Kommission der Deutschen Bodenkundlichen Gesellschaft in Berlin und Rostock. 
Reuter, G. 1958a. Anwendung genetisch-morphologischer Horizontbezeichnungen. Wiss. Abh. Dtsch. Akad. Landw. Berlin, 37, 268-280 (Festschrift Nehring).

Reuter, G. 1958b. Bodentypen in Mecklenburg. Wiss. Z. Univ. MR - Rostock, 7, 663-669.

Reuter, G. 1960. Eutrophe Pseudogleie auf Würm-Geschiebemergel. In Transactions of the 7th International Congress of Soil Science, Madison, Wisc. USA, Vol. IV, pp. 212-217.

Reuter, G. 1964a. Vergleichende Untersuchungen an lessivierten Böden in verschiedenen Klimagebieten. In Proceedings of the 8th International Congress of Soil Science, Bukarest, Vol. 5, pp. 723-732.

Reuter, G. 1964b. Zur Mikromorphologie lessivierter Böden in verschiedenen Klimagebieten. In Soil Micromorphology (Jongerius, A., ed.), pp. 213-218. Elsevier Publ. Co., Amsterdam.

Reuter, G. 1968. Lessivé soils in different climatic regions of Europe and North America. Pochvovedenie, 8, 62-70.

Reuter, G. 1982. Ertragsverhältnisse bei den Rostocker Dauerversuchen zur Humusbildung im Boden. Tag.-Ber. Akad. Landwirtsch. Wiss. DDR. Berlin, 205, 87-95.

Reuter, G. 1990. Disharmonische Bodenentwicklung auf glaziären Sedimenten unter dem Einfluß der postglazialen Klima- und Vegetationsentwicklung in Mitteleuropa. In Hohenheimer Arbeiten, Tag. Bd. Ernst-Schlichting-Gedächtnis-Kolloquium, pp. 69-74.

Reuter, G. 1994. Type interferences in soil. In Proceedings of the 15th World Congress of Soil Science, Acapulco, Mexico, Vol. 6, pp. 410-411.

Reuter, G. 1999. Profilmorphologische Studie zur 'disharmonischen' Polygenese von Podsolen. $Z$. Pflanzenernaehr. Bodenkde., 162, 97-105.

Reuter, G. 2000. A logical system of paleopedological terms. Catena, 41, 93-109.

Reuter, G. 2003a. Bilder mit Erläuterungen zur Geologie und Bodenentwicklung in MecklenburgVorpommern. Ingo Koch Verlag, Rostock. CD-ROM.

Reuter, G. 2003b. Disharmonic soil-type interference on Late-Pleistocene and Holocene sediments in North-East Germany. Ingo Koch Verlag, Rostock. CD-ROM.

Reuter, G., Jordan, E., Leinweber, P. \& Condo, A. 1995. Eigenschaften, Entwicklungstendenzen und Altersunterschiede von Moränenböden in den bolivianischen Anden. Petermanns Geogr. Mitt., 139, 259-262.

\title{
Hilispleistotseeni ja Holotseeni setetel kujunenud mullatüüpide harmooniline ja disharmooniline seostatus Kirde-Saksamaal
}

\author{
Gerhard Reuter
}

Kasutades värvifotosid ja horisontide erinimetusi, on esitatud Kirde-Saksamaa mullaprofiile, mis näitavad moreenil arenenud harmoonilise mullatekke iseloomulikke tunnuseid nüüdisaegseis kliimatingimusis ning disharmoonilist arengut lessiveerumise, pruunmullatekke, leetumise ja näivgleistumise tunnuste koosesinemisel. Muudes kliimapiirkondades tehtu põhjal on disharmoonilist mullateket põhjendatud kui Holotseeni jooksul toimunud kliimamuutuste tulemit, seda enam, et suhteliselt väheste sademetega rannikualal Boreaalis tekkinud reliktne mustmuld allus pruunmullatekkele. Huumus-raudilluviaalseid leede- ja leetunud muldi vanadel luiteliivadel on käsitatud väljundina Preboreaalis toimunud ferralluviatsioonist. 